Journal of Development and Communication Studies, Vol. 8. No. 1, January -June, 2021 ISSN (Online \& Print): 2305-7432. http://www.devcomsjournalmw.org

\title{
Neglected Aspects in the Understanding of Holistic Development in Africa
}

Augustine Chingwala Musopole, Emeritus Associate Professor, Department of Philosophy and Religion, Chang Jung Christian University, Tainan, Taiwan. E-mail: acmusopole@gmail.com ${ }^{3}$

\begin{abstract}
How does one explain Africa's underdevelopment when compared with other regions of the world? Over fifty years of independence have little to show for economic progress and poverty has continued to afflict the African population even as it continues to grow. Political instability, economic regress, corruption, and bad governance have been identified as some of the problems facing Africa and keeping it underdeveloped. Yet, I believe that there are still other matters that have been neglected preventing leaders coming up with a holistic vision of development. Attention to these neglected aspects would, most likely, contribute to removing the bottlenecks to more accelerated holistic development of the continent thereby making it possible for Africans to realise abundant life.
\end{abstract}

Keywords: development, agrarian, industrial, religion, umunthu/ubuntu/utu (humanness), state development, governance, worldview, blessed development.

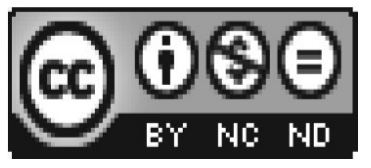

(C) 2020. The author. This work is licensed under the Creative Commons Attribution 4.0 International License (CC-By-NC-ND). Users may freely share and redistribute this work provided that the author and the Journal of Development and Communication Studies are fully acknowledged. Users may not tweak or remix and offer this work for sale. The full license may be accessed at https://creativecommons.org/licenses/by-nc-nd/4.0/

${ }^{3}$ Former Associate Professor, is ordained minister of the Presbyterian Church USA, a national of Malawi and author of "Being Human in Africa: Towards a Christian Anthropology", Peter Lang, New York, 1994, and "Umunthu, Ubuntu, Utu: An Introduction to an African Philosophy, Lambert Academic Publishing, Moldova, 2018. 
To cite this article: Musopole, A.C. (2021). Neglected Aspects in the Understanding of Holistic Development in Africa. Journal of Development and Communication Studies, 8(1), 202-223 https://dx.doi.org/10.4314/jdcs.v8i1.10

\section{Introduction}

The development of Africa has proved to be enigmatic and elusive in terms of its growth from an agrarian to industrial stage when compared to Asian countries that had experienced colonisation at the same time and for almost the same period. The verdict has been expressed in the following terms:

In short, given the opportunities, the resources, and the power and influence of the colonial rulers, they could and should have done far more than they did for Africa. And it is for this failure that the colonial era will go down in history as a period of wasted opportunity, of ruthless exploitation of resources of Africa, and on balance, of the underdevelopment and humiliation of African people. (Ohaegblum, quoted in Kashambuzi, 2001:15) ${ }^{4}$

This phenomenon has raised a variety of theories as to why this is the case. The problem might have to do with the historical reality of Africa on the one hand, and the definition of development as it relates to Africa on the other. However, this paper argues that there have been some critical, but neglected aspects in the understanding of African development which have also contributed to a large extent to this underdevelopment.

\section{The colonial ethos and African reality}

David Livingstone (1813-1873), the missionary explorer with the London Missionary Society, defined the missionary task that was meant to spearhead development in southern Africa as consisting of three Cs, namely, commerce, civilisation, and Christianity and in that order. Commerce was necessary with a view to healing what he called "the open sore" caused by the Arab slave trade on the East African coast. Arabs on the East African coast were involved in trading in human cargo and elephant hunting for their tusks. The human cargo also acted as transporters of the material goods, namely, elephant tusks, clothing, salt, and minerals. This trade penetrated into the interior of the continent and caused much human suffering. Civilisation was meant to bring about western cultural practices and attitudes through the introduction schooling and the Christian faith, economic activities to replace slave trading, the growing of cash crops to feed the factories in Britain. Christianity was for the improvement of the moral quality of what were termed the benighted African

${ }^{4}$ Festus Ohaegblum, quoted in Kashambuzi, Eric; Africa's Lost Century, Orlando: Rivercross Publishing, Inc., 2001, p. 15 
people, to bring about moral light to a Dark Continent through evangelisation and education, and secure for them eternal salvation beyond their joining the ancestors. However, his was a holistic vision under God, and so he was able to say, "Do not think me mad. It is not to make money that I believe a Christian should live. The noblest thing a man can do is, just humbly to receive, and then go amongst others and give."

${ }^{5}$ Nevertheless, the colonialism that overtook Christianity in the name of capitalism was not as holistic or even as godly as David Livingstone had expected it to be.

The African societies had mostly settled for either a pastoralist or agrarian way of life informed by their worldview and everything in between in their small linguistic communities only to be disturbed by the intrusion of foreigners from either within or without the continent. ${ }^{6}$ There was little, but steady industrialisation before the onset of colonialism, and not far distant from what was happening in Europe at the time. It was partly the industrial revolution in Europe and the need for raw materials that brought about the colonisation of Africa. The Berlin Conference of 1884-85 on the partition of Africa sealed the fate of the African peoples. This led to settlements along the coast, the exploration of the hinterlands, the construction of the railways systems into the interior of the continent, road networks, manufacturing for both the local and overseas markets. However, all this was being done for the wellbeing and welfare of the local white elite, the settler community, and the needs of the home industries at the expense of the African majority who were reduced to be hewers of wood and drawers of water. The Africans were left to occupy the lowest place in the racial hierarchy that was created in their own land while the Asians and Muratoes or mixed race people occupied the spaces in between. The natural development of the African societies was disrupted and so too their cultural self-understanding was denigrated.

\section{European development model as irrelevant}

Development in Europe was a different story. It followed a natural progression from the Greek and Roman times. It was served by inter-territorial trade made possible by waterways, Roman imperial legal systems and highways, and diversification of goods and services as cities and social classes developed over time leading to the transformation of the feudal agrarian societies into urban and industrial ones. Even though nationalism had emerged out of the breakup of the Roman Empire, the Empire had left a cultural unity of cultural, a universal education system, and a shared legal culture. Soon it was the European nations that became empire-building nations and engaged in overseas trade and colonisation. The development of Europe had been

${ }^{5}$ https://www.azquotes.com/author/8949-David Livingstone

${ }^{6}$ There was much population movements within Africa on account of slave trading, pastoral movements in search of grazing lands, and political conflicts among the people. 
long in coming since the Dark Ages to reach the modern industrial state through the Renaissance, the invention of the printing press, and the increase in literally abilities for the majority of its people, and the Reformation. There was the move from feudal to urban societies as a result of trade, and the agricultural revolutions, and finally industrial revolution. Therefore, for the colonisers, it was a matter of transplanting the same development for their own comfort to Africa as motivated by capitalism and Christian missions. The government centres and missionary stations testify to this practice. They became models of development.

\section{Development in Africa was not for Africans}

Therefore, what came to Africa was an outgrowth of what had taken place in Europe and the Americas over a long time, and then super-imposed on the African societies, but without the cultural and technological forces that drove that development in those areas where it came from. The colonisers, settlers, merchants, and explorers wanted to turn Africa into their own capitalistic and cultural image for themselves as it were in their countries of origin. Their settlements in Africa were tied to the metropolitan capitals and administrations for the sake of the settler and administrative community. It was to be a trickle down development for Africans, but even that trickle was accidental and not aimed at them.

A story was told on British Broadcasting Corporation (BBC) of Harold MacMillan (1894-1986), who was the British Prime Minister (1957-1963), sending his Foreign Secretary, Sir Ian McCloud to find out whether the African countries were ready for independence since they were agitating for it. Upon his return, McCloud told the Prime Minister that the Africans were not ready. Now this was more than fifty years of colonial presence in most of Africa and yet the Africans were not prepared for self-rule. Then the Prime Minister asked what his advice would be. Sir Ian McCloud told him, "Give it to them, for if you do not they will never learn to govern themselves." The Africans were thrown at the deep end to swim or sink. This is a very telling anecdote in that the colonial government was not even preparing the Africans for self-government. African leadership was not in their plans when independence started being given in the late 1950s and early 1960s. It was during this time that Harold MacMillan made his famous "wind of change speech" in South Africa in February, 1960,7 in which he argued that political change was inevitable with far reaching consequences. It was to take another thirty four years for that change to be realised in South Africa. This was equally true of the missionaries who were quite happy to represent the African interests in government, but not prepared to involve

7 "Wind of change the original text", http://www.africanrhetoric.org/pdf/ayor\%206.2\%205\%20Harold\%20MacMillan\%20\%20The $\% 20$ wind $\% 20$ of $\% 20$ change.pdf 
them in leadership. In the Livingstonia Mission, it took over twelve years to ordain the first African ministers after they had finished their training and after pleading for it. In some missionary organisation, leadership transfer was hurriedly done when Ghana got its independence in 1957. This was also true of some missionary churches in which white control remained until the 1990s. They maintained a Missionary Council besides having the local church with the result that the African churches remained infantile in their operation.

Therefore, at independence, there was a huge gap to be bridged if development for the Africans was to be accelerated so as to catch up with that of the colonisers or even take a different pathway to that of the colonisers. It was meant to move societies from where the majority were still within subsistent pastoralist or agrarian economies so as to becoming capitalistic and industrial economies. This would mean economies being moved from being human life-centred to being money centred, or from being umunthu (humanness) centred to being material centred. But how could that happen without basing it on the African worldview and also going through the natural cultural progression that Europe and the Asian countries had gone through? Joseph Nyasani (2010:2) has rightly observed,

Some wise man once observed that an imitation model or, rather, the blind obsequiousness to the foreign rhythm and spirit, is the effective gag and permanent muzzle of any form of initiative as far as the imitator is concerned. This may be true or false but the point of import here is that a distorted effect can be felt from any state of divorcing a people from their cultural reality and from the very driving force of their evolutionary process. ${ }^{8}$

Since the whites were developing the colonised space for themselves, it was easy to make the linkage in selected areas where they lived with their metropolitan centres both near and far. Could it have been possible to concentrate on the development of pastoral and agrarian economies as foundational to modernising our trading centres and being linked to markets outside since the majority of our people were rural dwellers? Would it not have been necessary to move the rural masses from subsistent agriculture to learning how to produce more from less land by introducing better agricultural methods and breeds of crops and animals? ${ }^{9}$ Estate-tenant farming was introduced for the political elite only to flounder due to poor management and misuse of loans. Development could have had implications also for education for pastoral and agrarian productivity and not simply the teaching of agriculture for examination.

\footnotetext{
${ }^{8}$ Joseph Nyasani, Philosophy of Development: An African Perspective, Nairobi: Consolata Institute of Philosophy Press, 2010, p.

9 Janet Karim; "Let us add value to our agricultural products", 27/8/2020; Nation Malawi https://www.mwnation.com/let-us-add-value-to-our-agricultural-products/
} 
While population movements is caused by many factors, such an education could have contributed immensely to preventing the movement from rural to urban centres in search of employment since rural living would have been more attractive and sustainable.,

\section{Urban development by colonisers and Asians}

Having not participated in the creation of the urban economic development, it was not easy to become entrepreneurs overnight. It fell to the minority Asian communities to move from being petty shop owners to manufacturing industrialists since they were also connected to their countries of origin that were industrialising, namely, India and Pakistan. They became retailers and wholesalers. This group of British citizens were brought to build the railway lines and they stayed to become petty traders within the developing urban or rural trading centres which formed the railway stations. At independence, they were the merchant class while the majority of the Africans were the subsistence farmers and consumers of goods found in the Asian shops. The African shop owners depended on Asian wholesalers for their goods. This made them third class entrepreneurs. In certain areas most people did not have enough land to work since most of it had been alienated to the whites for their vast estates of cash crops. Many more still had become the poor labouring class on these estates. As a minority group, they have managed to secure an economic niche and control the retail shopping and industrialisation processing in many countries. Shopkeeping became the economic foundation for the group while educating their children to become accountants, doctors, engineers, lawyers, and industrialists. Furthermore, they more often than not lived as communal families and not as individuals. Marriages were done within the communities and not anyhow. In this way, they have kept their cultural, linguistic identity, and wealth intact from generation to generation. The first generation of a few Africans have joined this wealthy group and grown either "politically" or "corruptly" rich, but one wonders whether they will be able to sustain and pass this acquired wealth on to the next generation for further growth as the Asians have done over a century? For the Asians, they have developed an entrepreneurial culture as families which they have passed on from generation to generation.

\section{Market women in West Africa a missed opportunity}

In West Africa, it was the market women who were the petty traders while their men were involved in either long-distance trade or in the local palaver and drinking parties. The market women economic activity was a very natural economic development, and the women have continued to dominate the small-medium enterprises and are also becoming millionaires in their own right. However, patriarchy that dominated pre-colonial thinking could not acknowledge this critical 
reality for economic development. It is, yet, on these that further growth should have been founded had governance and planning acknowledged women's economic potential and involved them. In most of our cities and towns, it is the women who provide most of the employment and are able to sustain their families. Had it not been for mothers, in both patrilineal and matrilineal societies, most young men and women would not have been educated on account of absentee fathers who travel far for employment, but forget to support their families.

However, most African countries found that gap very difficult to bridge as they could not trust women with loans on account of patriarchal biases lack of acceptable collateral. Most women might not have excelled in formal education, but they did excel in entrepreneurial skills. Since they were required to have a male to validate their loan applications, most women dared not apply for such facilities, but rather worked hard and steadily. ${ }^{10}$ Therefore, governments found themselves dependent on external aid in order to take control of their own development as engaged in by men, an aid that came with many strings attached and conditionalities. It meant that the state had to undertake the business enterprises through the creation of parastatal corporations many of which performed and continue to perform disastrously. For instance, African national airlines have been loss-making enterprises simply because those managing them both boards and management were there to earn a salary and not to grow a business. They employed their friends and relatives even though it meant it overwhelmed the wage bill. Furthermore, their development was not going to be one that came out of their natural growth, but rather being induced from without through loans, to continue where the colonisers left off, but loans that soon became a debt burden. It was their time to eat and not to grow the business for later generation's employment. External aid is good when it is meant to augment what is already there doing well with a view to realising greater growth and not as the means for simply keeping the enterprise afloat which is the case with many parastatal corporations. This truth is applicable to economic, political, social, educational, and even religious growth. They are all suffering fron a developmental gap. Even grafting requires a living base for the grafted piece to grow in a health manner. The African worldview is that healthy basis and not the untried western culture that the middle classes want to emulate, but using stolen money.

10 "Do women have equal access to finance their business?" https://www.oecd.org/gender/data/do-women-have-equal-access-to-finance-fortheir-business.htm 


\section{State-Development did not go far enough}

African development has been spearheaded by what Thandika Mkandawire (1940$2020)^{11}$ has called State Development, that is, development planned and undertaken by the state and less so by private enterprises. However, the state development was motivated by self-serving political interests of the ruling parties. It is not surprising that in Kenya, electioneering is the best business in town. Campaigns for elections five years hence start even before the coming elections are done. Elections drive the political discourse and any political manoeuvrings are associated with the next elections and raise much suspicion. The result is that any development is supposed to serve the electioneering drive and not the other way round. As a consequence, development is compromised and often confused and corrupted. Furthermore, income disparities and distribution are glaring. A few are very reach and the majority are wallowing in poverty. There are rich regions and very poor regions in the same nation. Where agriculture was meant to be the basis for rural and national development, it is in disarray.

On independence, development focused on the overcoming of three enemies, namely, poverty, ignorance, and disease. To combat the three enemies money had to be made available for agriculture, education, and improving health services. President Hastings Kamuzu Banda of Malawi (d.1997) told Malawians that money was in the soil and that through hard work it could produce enough money for the development of other sectors. However, the wrong means of implementing agriculture did not result in wealth creation. Furthermore, the State could not be the only thinker, planner, and player in development without the involvement of all citizens for the sake of their own development. A dependence syndrome among the citizens was created by the one-party state. The State Development policy did not go far enough since the ruling political parties, that soon turned themselves into single parties, monopolised the thinking and planning by excluding other people from it. Even within the one-party itself no dissent of thought and alternative views were permitted for lack of democratic practice. The word of the leader was final. The intelligentsia were excluded, if not, exiled; the peasants were dictated to or moved into villages as was the case in Tanzania and Rwanda. The peasants did not pull along, but simply watched officialdom do its work even as production ground to a halt. This was seen as forced and imposed development and the workers falsified production figures. The petty bourgeoisie resented the party operatives for intimidating and exploiting them by demanding contributions to the party, contributions that were never accounted

${ }^{11}$ Godwin R. Murunga; "Codesria Tribute to Thandika Mkandawire, (1940-2020): Scholar, Mentor, and Institution Builder" https://www.codesria.org/Thandikamkandawire/2020/04/14 
for. All these groups could not identify themselves with the so-called development that was taking place in the name of the political leader and the party in power, but not for the people. Things continued in the same way they were during the colonial times only that the rulers were now Africans, but serving a small minority that belonged to the party in power.

\section{The Bretton-Woods Institutions and African Development}

Development policy was more often than not usually informed by the Bretton-Woods Institutions, namely, World Bank (WB) and International Monetary Fund (IMF) which in turn were and continue to be guided by neo-liberal economic ideologies which were developed and have been applied elsewhere in the world, simply, as one size fits all; a policy that never distinguishes historical realities and contexts; and using epistemologies that claimed universality when they were not. While Thandika Mkandawire has been of the opinion that State Development produced positive dividends in that African countries having achieved some impressive growths during the sixties and seventies, the Bretton-Woods Institutions introduced their Structural Adjustment Programmes (SAP) to relieve State Development of being overburdened with increasing debt due to economic crises of the mid-1970s. The proposed privatisation as the way forward in growing an economy plunged the African countries into economic decline during the 1980s and 90s. However, he is also right to point out that the lack of democracy did not allow such states to achieve continued greater growth. This was made worse by the impact of Cold War politics. By resorting to oppression and denying people their rights to criticize and offer alternative views, the state actually shot itself in the foot. All people continued to look to the state to plan for them and up to this day, one hears the same chorus, "We ask the government to help us" even where they can take care of themselves. To help with electioneering, the politicians have also tended to promote this complacent attitude.

\section{Vision 2020}

In 1998 the Malawi Vision 2020 was launched. The then ruling party, the United Democratic Front (UDF), had copied the idea of Vision 2020 from Malaysia and the World Bank as a government document. After the launch little much was heard of it. It was claimed that its visions had been mainstreamed within the various government policy documents and were being implemented piecemeal. However, there was little trace of them over the period. Many corporations, parastatals, and industrial enterprises collapsed. Many people lost their jobs and their terminal benefits were not paid.

The vision was not sold to the people of Malawi so as to own it as citizens, families, institutions, communities, areas, districts, and regions by being asked to develop their own Vision2020s, and that for the next twenty years they would be daily 
reminded of the same as to what progress they would have made in their visions or challenges they would have met and solutions made. This is what the new foundation for the national development could have meant.

Furthermore, the government has introduced a series of Poverty Alleviation Policy Documents since the1990s. Here again, the emphasis was on what the government was going to do and not what the people were expected to do. The private sector, including faith communities which were acknowledged as partners in development, did not figure in it as major players. Here again, economic projects were geared towards the electioneering process, done by the government for the people of a certain area as election promises, but not for the sake of their own development. Money meant for the Karonga-Chitipa road in the Northern Region was severally diverted to the southern region, the home of the President and the strongholds of the ruling party. This was done for over twenty years until when some people were killed as they demonstrated against its delayed construction. Even when it was constructed, it was named after a President who came from the Southern Region as demanded by the people from the area where the road passed.

\section{Lessons from the Asian Tigers: Taiwan, Thailand, South Korea, and Singapore}

African countries are not short on development visions. In their latest visions of development many African nations are desiring and determined to become middle income and industrialised economies within the next four decades, that is, 2063. ${ }^{12}$ This could only be done by leap-frogging, but the problem is how to achieve such a feat without going through the natural processes of development that other nations have gone through. This is where what has happened in Asia might become an eye opener to what is relevant, and that some lessons might need to be learned. While the development of Europe, America, Canada, Australia and New Zealand, and Latin American countries cannot be taken as models for African development, the Asian countries have much in common with African countries especially in the way they were colonised by the same European or Japanese countries while the homogeneity of their people and cultural differences notwithstanding. Therefore, the critical question has to be what enabled the Asian Tigers to leap-frog to becoming industrialised. Where did the African countries miss the boat?

Even in the case of comparing Asian Tigers with African counties, however, one wonders whether this is possible. Judging from the fact that within the number of years that most African countries have taken since independence, Asian nations have done so with excellence in spite of wars and even without democratizing in certain cases. How did they manage to move from being dependent on agriculture to

${ }^{12}$ https://au.int/sites/default/files/documents/33126-doc-01 background note.pdf. This vision was concluded in 2013, hence fifty years brings it to 2063. 
becoming industrialised and thus improving their per capita and moving the majority of people out of poverty? What has prevented African nations from doing the same for their people? What should they do to achieve the same results this time round?

Taiwan was colonised by Japan for fifty years from 1895-1945 and relied on sugar and other agricultural products for its economic base and development. Japan wanted Taiwan to be the bread basket for Japan, and therefore, provided scholarships for Taiwanese students to study agriculture in Japanese universities. It is reported in a book on the history of Taiwan that in 1934 there were over 3000 Taiwanese students in Japanese universities while there was no secondary school in Malawi. In the 1960s Taiwan experienced an economic boom especially in the agricultural sector. This meant that rural prosperity led the way towards the creation of light industries, for instance, textiles and plastics. In the 1980s it moved to capital intensive and knowledge-based industries, such as, steel, ship-building. Gradually there was a move to semiconductors and electronic products making Taiwan one of the world's largest producer of these goods. Export processing zones were established following an import substitution policy and direct foreign investment was promoted. ${ }^{13}$ There are several other factors that favoured rapid economic growth of Taiwan, namely, its geographical position as an island, its rich volcanic soils, irrigation schemes that the Japanese had put in place making it possible for crops to be grown twice a year, a well-trained human power, and coordinated planning involving government, industry, and academy. Improved transport infrastructure accompanied these developments, but were not the cause of it.

However, during the same time African countries continued to wallow in poverty, being debt ridden, and mismanaging their economies through self-serving dictatorships and application of foreign irrelevant ideologies instead of home-grown relevant thinking. Even those nations with coastlines did not fare any better. They have maintained the same small boats or canoes to this day for fishing. Remember, that Taiwan was also a dictatorship, but still progressed economically just as China is still a one-party state dictatorship and yet managed to become the second largest economy, its population notwithstanding. While Taiwan lacked the natural resources for its industries, it imported and manufactured for the global market. African countries continued to depend on the production of raw materials that did not fetch good prices at the world market. It lacked the technical know-how for secondary processing of the raw materials.

Africa continues to be a damping place of cheap goods produced elsewhere. Thus its home grown industries have faltered. Textile factories floundered in many African countries while second-hand clothing from developed countries have found

${ }^{13}$ https://www.britannica.com/place/Taiwan/Economy 
a lucrative market in Africa. In Ghana a whole tomato processing plant is idling in spite of tomato being available, and yet processed tomato from China and Italy finds a ready market among Ghanians. Its youth desire to go into Europe to pick the same tomatoes, sleep rough, and risk drowning in the Mediterranean Sea while land remains idle. Locally manufactured goods are not preferred over goods from overseas. Why is this the case?

\section{Decolonizing the developmental mind}

Colonisation brought with it a mindset meant to profit the colonisers and not the colonised. That decolonised mind was dictated to by certain epistemologies that were globalizing and dualistic in their orientation working with a binary logic of either/or, but not a relational one of both/and. It depended on a school system that aimed at head knowledge for employment and not of practical skills for wealth creation. It was either their way or nothing, their politics or nothing, their superiority or nothing, their profit or nothing, their conversion or nothing, and them as masters or nothing. African democracy was consensual, suspicious of absolute power, and promoted a communal economy (not collective or individual interest and profit). While we decolonised ourselves politically, we did not do so mentally, that is, our thinking remained colonised. We kept seeing reality with western theoretical eyes. The West dictated how we even looked at ourselves and continues to do so. It is common to refer to one's boss in Malawi as "Mzungu Wanga", that is, my Whiteman, my boss, my benefactor. Anything that is of a larger size is referred to as European, for instance, a dog, a tomato, an orange, a mango, a house, etc. In order to decolonise the African mind, there is need to retrieve a critical mind that has always been there, but rather got suppressed. It finds expression in the saying, "Ichi nchiani mulinga muli awili" meaning, one verbalizes a question with a view for an answer from others. Of course, the fact that one is able to ask, points to one being already involved in self-reflection. In other words, critical thinking is a communal exercise. The rise of political consciousness did not go far enough in self-decolonisation. It left the mind still colonised. How does this apply to the matter of development?

The problem seems to lie in the understanding of what development is and should mean on the one hand, and the unrealistic approaches that have been adopted that do not factor in certain necessary requirements. Writing on why Malawian agriculture has failed to prosper, Tamani Nkhono-Mvula has blamed what he calls the "institutional and structural environment in which it is being implemented", and that, hence, it needs serious structural reforms to bring about the best. ${ }^{14}$ Governments have initiated policies that were aimed at getting them re-elected and that created a dependency syndrome among the recipients of agricultural subsidies and other

${ }^{14}$ https://www.mwnation.com/thoughts-on-agriculture-sector-reforms-in-malawi/ 
projects. The policies did not to improve the recipients' moral integrity, wisdom, economic productivity, social solidarity and justice which are the major pillars of the African worldview. While agriculture remains key to being a foundation of any economic development, it needs to be properly harnessed for the benefit of the people and not for political electoral needs and capitalistic interests.

Structurally, upon independence, the African countries continued the exercise of their development on the same basis as was being done during the colonial times only that the rulers were now Africans and not white colonialists. A few attempted the socialist route, but found it difficult to succeed within a world dominated by capitalism. Even China had to adopt state capitalism during the time of Deng Xiaoping (1904-1997). Those who joined the table were now many more than the colonial government were able to cater for. It needed the miracle of Jesus feeding the five thousand from a few pieces of fish and bread. ${ }^{15}$ The miracle did not take place. Many continued to be hungry and assistance had to be sought from elsewhere. The methods remained the same only that the exploiter of the system was now the African elite seeking to become rich through corrupt places through the exploitation and manipulation of the governance systems. The consequence was not only neocolonialism driven by the industrialised nations, but also in collusion with the Africans themselves exploiting their fellow Africans worsened the economic conditions for the majority of the citizenry. Corruption became endemic and development was skewed.

\section{Wrong European models for African development}

The models of development remained European and American that created a dependency syndrome on account of being captive to a decolonised mind, and yet these countries had gone through their own agrarian revolution many centuries ago and had by now industrialised following their own agricultural reforms, private investments, democratic practices, and the rule of law that exalted the individual over the community. Their industrial economies were no longer dependent on agriculture even though they had been spurred by it, but rather through innovation and personal investments they grew major industries for the global market through what US President Dwight Eisenhower (1890-1969) called the "military-industrial complex". Therefore, they were not the right models for African development even though a few lessons could be learned from them. Their historical conditions were not the same as those obtaining within Africa. It needs to be acknowledged that all revolutions are messy even when handled carefully since not everyone is ready for them. Europeans moved from feudalism through agricultural reforms to industrial revolution as a natural progression and the mess it created. They had undergone two world wars and

${ }^{15}$ Matthew 14:13-21 
many more small ones that spurred technological advancement applicable to civilian life. How could the African countries catch up to them within a very short time span and the messy that are entailed?

Each western nation undertook its own development within its own given worldview over time, namely, the Greco-Roman and the Judeo-Christian civilisation in case of Europe. However, since colonialism had dealt a death blow to the African worldview, the African leadership continued with the building of the new nations from the foundation and understanding that the colonialists had left in place, a foundation meant for white prosperity and not black progress. In comparison, the Asian Tigers adapted the Western successes to their Confucius and Buddhist cultural worldviews with its humanistic understanding; culture of hard work motivated by the realisation of Nivarna; and a creative curiosity into how nature works. Western knowledge was an additional to their native knowledge which they have not given up on to this day. Their minds were not colonised such that even communism had to have a Chinese face. All this marked a great difference as to the success that was to be realised when it came to development. The Asians excelled where the African fumbled by not giving up on their own religious imbued worldview, but rather adopted and adapted the Western contribution to it.

The African leadership might have known who it was against in the process of colonisation, and not what it was for. While they should have been for the total decolonisation of the African, namely, the mind, spirit, and body on the negative side, they should also have been for the realisation of abundant life based on the African worldview to which modernity was to be adopted and adapted, but not the other way round. Of late, Kenya has been exploring through the Building Bridges Initiatives where the nation could cohere. Reading the content on national ethos, it is so shallow and gives the impression that they still do not know who they are and what their worldview is.

Be it Indirect Rule of the British or assimilation policies of the French and the Portuguese, both colonialist approaches were aimed at alienating Africans from their African worldview and to be at the mercy of the white economy and worldview. It was imperative that a critical and analytical view should be adopted by the African leaders so as to identify who they were as Africans and what they fought to preserve, namely, a communal abundant life outlook; the umunthu character based on integrity, wisdom, and economic productivity (umunthu/humanness); social solidarity and the practice of justice; and being a community-in-communion. It is only such an outlook that could lead to a blessed development. 


\section{Higher Education for umunthu and development}

Since colonialism existed for the prosperity of the white race, be it colonies or protectorates, colonialists had no interest in educating the black people to their own level, and hence they controlled the development of education. Had it not been that missionaries made education both an evangelizing and civilizing tool, colonial support for the development of education would have been very minimal indeed. For instance, in the then Nyasaland (now Malawi), the colonial government introduced grants-in-aid to support missionary schools in 1927, almost 27 years since the introduction of British rule. Most of the education in Malawi went as far as Standard six, currently eight, of primary schooling. Rev. Dr. Robert Laws, leader of Livingstonia Mission, had plans for a university at Khondowe in 1915, but was prevailed upon by his home committee not to continue with the project because the Africans did not deserve it. It took another one hundred years to have a Livingstonia University. Had this university been established then, the development would have been massive since even the education they offered was revolutionizing the life of the African people in spite of it being controlled.

In most of our countries, university education started in earnest after independence. There were only five independent universities in 1960 in Liberia, Ethiopia, Sudan, Senegal, and Congo-Leopoldville (now DRC). ${ }^{16}$ University education was patterned on western curriculum models mostly British, French, Belgian and American, and have continued to remain mostly the same with a few cosmetic changes regarding the teaching of literature and history. It was liberal education that was promoted mostly focused on the humanities and meant for the ruling class and those who would assist it to rule among the Africans. African universities have continued to look to the West for the validation of their content, standards, and classification of their excellence. The aim for the introduction of higher education was to provide an administrative cadre to replace the colonial officers. However, that need was soon met and unemployment ensued. Universities continues to produce graduates for whom there were no jobs. This was a good sign for political and education leaders to change tact, but they did not due to being captive mentally to Western canons of higher education. While African school systems are still colonial, elitist, and at best culturally irrelevant to African development, Asian countries adopted the Western system of education to their cultural and developmental needs by opting to use their own languages and not the foreign ones, and also changing the curriculum to suit their needs.

Languages carry the worldview of a people; hence foreign languages tend to alienate the people from themselves, foster social and economic classes in a nation,

${ }^{16}$ Eric Kashambuzi; Africa's Lost Century: Who is Responsible? Orland, FL.: Rivercross Publishing, Inc., 2010, p. 165 
and thus, lead to a fragmenting of society. Language as a communicative tool is critical to the transmission of knowledge needed for the maturing of any people. While some local languages are being taught as designated national languages, they are not used for teaching other subjects except Swahili in Tanzania. This limited use of language can only undermine the transmission of the African worldview with its existential meaning for the people concerned. It also limits the growth of that worldview and thus contributes to the poverty of the mind. The need for the promotion of local languages and cultural studies is one way of counteracting the negative and alienating effects of colonialism, but they need to be used as a teaching language and to provide a worldview. In this respect, the translation of the Bible into many local languages has contributed much to local language development and to literacy. However, it is the biblical worldview that has been established at the expense of the African worldview. The Bible is the one book that many have in their local language to maintain and sustain their literally skills. The use of local language for adult education is critical for the illiterate. Furthermore, even though we are condemned to use foreign languages, we can still grow our own and critically use the foreign languages in a manner that promotes our own worldview and thought forms. We can be proud Africans in our thinking and attitudes even though condemned to using European languages.

The many languages in most of our countries can only be a challenge to faster societal transformation, and yet even the common foreign languages that we use are known by a few. In former British colonies and protectorates, English was for the office and not a street language as was the case with French and Portuguese colonies where the foreign language could be picked on the street and farm. Until English becomes a street language, it will continue to remain a foreign, though official language, in Malawi and not a Malawian language. Language, as that which communicates a people's worldview and existential meaning, is critical to any meaningful development of a nation.

\section{Transforming the school curriculum for development}

Following the technological contribution to development in Asia, African countries have changed their school curriculum to one based on Science, Technology, Engineering and Mathematics (STEM), to be done at the expense of the humanities and social sciences. Kenya is in the process of introducing a competence based curriculum which emphasizes the development of skills and knowledge to be applied to life's real situations. ${ }^{17}$ However, this abrupt change might not produce the desired results not without incorporating the African worldview and existential meaning that

\footnotetext{
${ }^{17}$ https://kenyayote.com/what-is-competency-based-curriculum-cbc-in-kenyadetailed-illustration/
} 
governs the understanding of many people both in the rural and urban contexts. We may have just shifted our perception, but not removed the actual developmental bottlenecks created by the colonial gap between the two.

Sometime back I asked a science graduate teacher concerning the science of sima-/ugali-/ papu-/18 making during an interview, he could not answer the question because he was never taught it in class and, therefore, could not apply his science knowledge to what his grandma knew best. There was a developmental disjuncture between his schooling and lived experience. Science has to be rooted in our worldview experience otherwise it won't be applied appropriately. Many students fail on account of not understanding the foreign language. While agriculture has been taught in primary and secondary schools, many students learned it for examination, but never applied that knowledge in their rural communities to solve local problems. If schools had taken an interest in African scientific developments, for instance, beer making, the distillation of spirits, namely, chang'a in Kenya and Kachasu in Malawi, the adulteration of the product leading to fatalities would have been prevented. The knowledge gap would have been overcome. However, following the Asian model uncritically will lead to the misapplication of any knowledge and hence to miss on meaningful development. The Asian context is not the same as the African context, and hence the African context needs its own path ways to development which may need to be define differently, but appropriate to the African people.

Furthermore, curriculum developers seem to under-estimate the intelligence of the African child because their models are Western in terms of child psychology which is applied as if one size fits all. Most of what is found in textbooks is more often than not below the student natural ability to learn and limiting in its content spread; and sticking to those textbooks severely limits the pupils' intellectual progress. It is not simply knowledge for its own sake or for examinations' sake that is needed, but knowledge applied to problems within the local context and to human needs globally. There is need to think and act locally and being globally open to other perspectives. Therefore, one of the best ways to that existential knowledge is learning the value of the question mark (?). This is where the child also begins, however, more often than not, the child is discouraged from being over inquisitive. Charles Dickens in his novel Great Expectations has this idiom, "Ask no questions, and you'll be told no lies."19 This can only pour cold water on a child's curiosity and inquisitiveness. And yet, this happens very often in many cultures.

If Africa is to industrialise, then computer and electronic studies should be introduce in grade one. Children should be introduced to the battery, the circuit

\footnotetext{
${ }^{18}$ Name for local food stuff made from mostly corn flour and other cereals. ${ }^{19}$ https://www.goodreads.com/quotes/536104-ask-no-questions-and-you-ll-be-told$\underline{\text { no-lies }}$
} 
board, and to computer programming, and to also what these could be applied. Kenya promised a tablet to every child beginning school, but it is yet to be fulfilled after eight years. It was part of the electioneering process. Easily said than done. Seen from the manner children understand the use of the remote-control to manoeuvre through various programmes and sections of smart TV better than adults do, points to their fast learning ability which curriculum designers seem to underestimate. It is the adult teachers who do not know, and hence become a hindrance in the children's academic progress. Unless we see development starting with the child the overall progress of a people will be slowed down. After all, children are also very good at transmitting knowledge to adults than adults to children.

\section{Religion and development}

While religion is barely tolerated in the public space in a world that is becoming more secular, its contribution to development remains contested and even not recognised as being significant to development as a whole. The tendency is to relegate it more and more to the private domain. In spite of its past and current contribution to various aspects of development, it is more and more being pushed to the periphery or intellectually dismissed as the opium of the masses as described by Karl Marx. Religion is, therefore, another aspect of development which has become a forgotten or misunderstood phenomenon in the historical life of nations. Even though more often than not many countries in Africa take religion as a partner in development, it is largely on account of its pioneering work in education, health, and technical skills training. The current crop of university students is becoming more secular than religious. The spiritual aspect of its work is less appreciated as being critical to national development. Yet, the truth that righteousness exalts a nation while sin brings about the downfall of any society cannot be denied. Otherwise, we could not have the criminal justice system, the rehabilitation centres for addicts, and the counselling industry to attend to people who are failing to cope with the vicissitudes of life.

The spiritual and social work of religion has to do with the development of wise and moral character in the course of human development. This was largely the focus of traditional education, spirituality, and communal cohesion. At the heart of the African worldview is the concern for the securing and flouring of life; and at the heart of that flourishing of life is the concern for the development of a moral character based on ubuntu/umunthu/utu or humanness. Humanness is one of the gifts of a Creator and his designs as opposed to unyama, that is, wildness. Human character formation and development towards its maturity has to be the foundation of all development. Relevant African development starts from here and ends with technology and infrastructure, but not the other way round. It is the corrupt human 
being that corrupts the world and also corrupts technology. It is the corrupt humanity that is responsible for environmental degradation and pollution.

Properly defined, religion has to do with the meaning of human existence from conception to beyond death. Religion as a belief system is secondary to the existential meaning that responds to the question, "Who am I?" From an African worldview point, the answer is, "I am because we are, and since we are, therefore, I am" 20 as John Mbiti presented it. Therefore, religion cannot be confined to the private domain unless our own humanness is also confined there. To relegate it to the private domain is a liberal fallacy informed by pretended human autonomy. Since humanity is not selfmade by evolution or creation, it cannot be autonomous. Religion as rooted in love, and freedom belong to the market for a "willing buyer" and a "willing seller". When religion becomes isolationist and monopolistic, it cannot serve the flourishing of humanity since it is bound to be oppressive, discriminatory, and even, sexist. In that way, it cannot contribute positively to human development and flourishing.

At the heart of genuine religion is the love ethic. Love is the image in which humanity is created and the only energy that humanizes while anything contrary only dehumanizes. Love is the one common denominator of all religious expressions. They all converge on love. Love is what constitutes freedom and freedom calls for responsibility and accountability in mutual service. Mutual service leads to the formation of communities-in-community as families, political parties, corporate organisations, trade unions, and worshiping communities, and social organisations in pursuit of solidarity and just relationships.

From a religious point of view, development goes beyond infrastructure to the flourishing of the human spirit and moral character. It goes beyond the per capita increase, profit-making and material accumulation by a few. Development has to be accompanied by blessings both spiritual and material for the joy of humanity through the deepening of the meaning of human existence, the creation and just distribution of wealth, social solidarity and justice, and being a community-in-communion. Religion exists to provide hope and eternal security for all the people beginning in the here and now when the victory of good over evil is made real, and so too life over death. The current problem is that for many, in spite of material security, they find life to be hopeless and without meaning and hope, leading to addictions of all sorts that make their situations worse; to greater poverty, ingrained injustice, wide spread corruption, and to suicides at a very early age for failing to cope. Finally, there is an increase in mental ill-health and domestic violence in today's society. This is true of industrial and urbanised cultures as well as rural ones. As such, these are not signs of abundant life which is the mark of genuine development.

${ }^{20}$ See the first chapter of John Mbiti, "African Philosophy and Religions" Nairobi: East African Literature Bureau, 1969 


\section{Africa and sustainable development goals}

In the light of the above, how do the Sustainable Development Goals measure up within the African context? Seventeen goals have been identified and yet when there were only 8 millennium development goals, most countries did not even realise half of them. Now, the 17 goals are: No poverty, no hunger, good health, education, gender equality, clean water, clean energy, economic growth, industry and infrastructure, no inequality, sustainability, responsible consumption, climate action, life under water, life on land, peace and justice, and partnership. ${ }^{21}$ While all these have a place in the pursuit of development, they need to be contextualised, and it is here that the African worldview becomes critical to their realisation. Since the African worldview is centred on "the Community of Life" that is anthropocentric, it is the human character or humanness that needs to inform these goals for them to be sustainable and developmental. Proposing them from a neo-liberal, an individualistic economic point of view that does not take into account the African reality would not fundamentally alter the current African situation.

Development experts ignore the role of the African worldview on the one hand, and that of religion on the other hand at their own peril since these can be great positive forces for good in the realisation of these sustainable development goals. Religion is at the very heart of culture, humanity, and human personality as a contributor to existential meaning. Even secularism as a search for an alternative existential meaning becomes a religion against other religions since religion is at the heart of every cultural expression, otherwise, culture loses its meaning. Ludwig Feuerbach (1804-1872) made the mistake of rupturing the cultural connection between religion and culture by reducing heaven to nature, which then Karl Marx (1818-1883) dismissed as non-essential to humanity, an opium of the masses. As a consequence, Friedrich Nietzsche (1844-1900) declared God dead and that humanity was alone in the cosmos. With a dead god, Vladimir Lenin (1870-1924) sacrificed millions to celebrate the death of this god and the enthronement of the Communist Party in Russia. Vodka became the spiritual energy.

The God who is the "I am that I am"22 is a God of life and desires to share that full life with humanity. To deny the existence of God, as Karl Marx did, and to treat such religion as an opium, is to deny a bourgeoisie idol god and not the God who encounters us in our humanity as the living God, the I am that I am. Only a person who is dead to God can deny the existence of a God whose very nature is to be and to

${ }^{21}$ https://www.sightsavers.org/policy-and-advocacy/globalgoals/?gclid=EAIaIQobChMIOfWsLyv6wIViPdRCh3EtgGpEAAYASAAEgKU7PD BwE

${ }^{22}$ Exodus 3:14 
condition in love the existence of even the one denying him. The God who is life is the God who blesses and without that blessing there cannot be meaningful existence and development. The biblical writer to the Hebrews also states, "And without faith it is impossible to please him, for whoever would draw near to God must believe that he exists and that he rewards those who seek him." 23

\section{Concluding remarks}

Genuine and authentic development has to begin with the development of our humanity. When one reads ancient religious texts one sees that humanity has been on a path of moral decline and, therefore, is failing to match up with its technological development. This might be one reason why we tend to define ourselves technologically as either primitive or advanced, non-industrial or industrial, technologically backward or advanced. Those who are technologically more advanced are deemed to be better human beings, and those who have been left behind are deemed to be less human and are treated as such. Africa has been a victim of this perception and continues to be, and hence the desire for Africa to catch up with the rest of technologically advanced countries while sacrificing its humanness. The technological wars that we are seeing are not simply economic or political, or about security concerns, but much more about self-definition as human beings. Americans consider themselves as more human than the Chinese, hence "America first" mantra, and the Chinese advancement is a great threat to that perception. Hence, the Chinese have to be painted as morally deficient and thus less human. They are the diseased and source of diseases.

Thandika Mkandawire understood that "the main challenge of development was the establishment of state-society relations which are (a) developmental, in the sense that they allow the management of the economy in a manner that maximises economic growth, induces structural change, and uses all available resources in a responsible and sustainable manner in highly competitive global conditions; (b) democratic and respectable citizen's rights; and (c) socially inclusive, providing all citizens with a decent living and full participation in national affairs." Therefore, good

governance had to do with how well it sustained the three points mentioned above. ${ }^{24}$ The state-society relationships that Thandika Mkandawire mentions, upon deeper analysis, can only be founded on an African worldview with its emphasis on humanness (umunthu/ubuntu/utu/) moral character construction as a religious reality.

\footnotetext{
${ }^{23}$ Heb. 11:6

${ }^{24}$ file:///C:/Users/User/Downloads/Tribute to Thandika Final.pdf p. 5)
} 


\section{References}

Kashambuzi, E. (2001), Africa's Lost Century: Who Is Responsible? Orlando: Rivercross Publishing, Inc

Magesa, L. (1997), African Religion: The Moral Tradition of Abundant Life, Nairobi: Pauline Publication Africa

Nyasani, J. (2010), Philosophy of Development: An African Perspective, Nairobi: Consolata Institute of Philosophy Press

Storrar, W. and Morton, A. (eds.)(2004), Public Theology for the 21st Century, London, T\&T Clark 